\title{
Small-scale, semi-automated purification of eukaryotic proteins for structure determination
}

\author{
Ronnie O. Frederick · Lai Bergeman · Paul G. Blommel $\cdot$ Lucas J. Bailey $\cdot$ Jason G. McCoy $\cdot$ \\ Jikui Song · Louise Meske · Craig A. Bingman · Megan Riters • Nicholas A. Dillon • \\ John Kunert · Jung Whan Yoon · Ahyoung Lim · Michael Cassidy · Jason Bunge · \\ David J. Aceti · John G. Primm · John L. Markley · George N. Phillips Jr · Brian G. Fox
}

Received: 7 August 2007/ Accepted: 16 October 2007/Published online: 6 November 2007

(C) The Author(s) 2007

\begin{abstract}
A simple approach that allows cost-effective automated purification of recombinant proteins in levels sufficient for functional characterization or structural studies is described. Studies with four human stem cell proteins, an engineered version of green fluorescent protein, and other proteins are included. The method combines an expression vector (pVP62K) that provides in vivo cleavage of an initial fusion protein, a factorial designed auto-induction medium that improves the performance of small-scale production, and rapid, automated metal affinity purification of His8-tagged proteins. For initial small-scale production screening, single colony transformants were grown overnight in $0.4 \mathrm{ml}$ of auto-induction medium, produced proteins were purified using the Promega Maxwell 16, and purification results were analyzed by Caliper LC90 capillary electrophoresis. The yield of purified $\left[U_{-}{ }^{15} \mathrm{~N}\right]-\mathrm{His} 8-\mathrm{Tcl}-1$ was $7.5 \mu \mathrm{g} / \mathrm{ml}$ of culture medium, of purified $\left[U_{-}{ }^{15} \mathrm{~N}\right]-$ His $8-G F P$ was $68 \mu \mathrm{g} / \mathrm{ml}$, and of purified selenomethione-labeled AIA-GFP (His8 removed by treatment with TEV protease) was $172 \mu \mathrm{g} / \mathrm{ml}$. The yield information obtained from a successful automated purification from $0.4 \mathrm{ml}$ was used to inform the decision to scale-up for a second meso-scale $(10-50 \mathrm{ml})$ cell growth and automated purification. ${ }^{1} \mathrm{H}-{ }^{15} \mathrm{~N}$ NMR HSQC spectra of
\end{abstract}

R. O. Frederick · L. Bergeman · P. G. Blommel ·

L. J. Bailey · J. G. McCoy · J. Song · L. Meske ·

C. A. Bingman - M. Riters - N. A. Dillon - J. Kunert .

J. W. Yoon · A. Lim · M. Cassidy · J. Bunge ·

D. J. Aceti · J. G. Primm · J. L. Markley ·

G. N. Phillips Jr · B. G. Fox (ه)

The University of Wisconsin Center for Eukaryotic Structural

Genomics and Department of Biochemistry, University

of Wisconsin, Room 141B, 433 Babcock Drive, Madison,

WI 53706, USA

e-mail: bgfox@biochem.wisc.edu
His8-Tcl-1 and of His8-GFP prepared from $50 \mathrm{ml}$ cultures showed excellent chemical shift dispersion, consistent with well folded states in solution suitable for structure determination. Moreover, AIA-GFP obtained by proteolytic removal of the His8 tag was subjected to crystallization screening, and yielded crystals under several conditions. Single crystals were subsequently produced and optimized by the hanging drop method. The structure was solved by molecular replacement at a resolution of $1.7 \AA$. This approach provides an efficient way to carry out several key target screening steps that are essential for successful operation of proteomics pipelines with eukaryotic proteins: examination of total expression, determination of proteolysis of fusion tags, quantification of the yield of purified protein, and suitability for structure determination.

Keywords Eukaryotic protein - Protein production . Protein purification · NMR · X-ray crystallography · Protein Structure Initiative $\cdot$ Maxwell

\section{Introduction}

The productivity of high-throughput structural genomics endeavors is critically dependent on how efficiently the best target proteins for structure determination can be identified $[1,2]$. This applies to natural proteins as well as to products of engineering strategies, such as domain subcloning [3-5], modifications of the $\mathrm{N}$ - and C-termini [6, 7], surface entropy reduction [8,9], and chemical alkylation of lysines [10]. The pipeline used by most structural genomic centers defers the evaluation of whether a target protein is amenable for structure determination until after the target protein has been successfully produced and purified in quantities of tens of milligrams. This approach 
is expensive, because many important characteristics that determine whether a protein is suitable for structure determination, for example its stability, whether it is wellfolded in solution, and whether it can be crystallized, only become apparent during ${ }^{1} \mathrm{H}-{ }^{15} \mathrm{~N}$ HSQC measurements [7, $11,12]$ or crystallization screening [13-15], and this is after considerable labor and resources have been expended.

Ideally, a bioinformatics evaluation would identify proteins best suited for structure determination [16, 17], but it is still difficult to significantly improve the output of protein structures based on this approach alone [18, 19]. Consequently, experimental methods to identify the best proteins are still required, and obtaining predictive results as early in the production pipeline as possible and with minimal labor and resources used has become a focus of much effort [20-27].

The Center for Eukaryotic Structural Genomics (CESG) has worked to develop simple, efficient small-scale screening methods that successfully predict the results of large-scale protein purification. In previous studies, we have examined individual steps in the protein production and structure determination process [28-31]. Recently, we have begun to combine improvements in expression vector engineering [32], in vivo fusion proteolysis of fusion proteins [33], and factorial evolution of auto-induction medium [33] with a bench top, automated method to prepare highly purified proteins required for structural evaluations. Here we show that this combination enables rapid production of labeled proteins that can be used directly in NMR and X-ray studies.

\section{Materials and methods}

\section{Chemicals}

Unless otherwise stated, bacterial growth reagents, antibiotics, routine laboratory chemicals, and disposable lab supplies were from Sigma-Aldrich (St. Louis, MO), Fisher (Pittsburgh PA) or other major distributors. L-Selenomethionine was from Acros (Morris Plains, NJ); $\left[U_{-}{ }^{15} \mathrm{~N}\right]-$ $\mathrm{NH}_{4} \mathrm{Cl}$ (98\%) was from Cambridge Isotope Laboratories (Andover, MA). Preparation of standard laboratory reagents was as previously described [34]. Deep-well growth blocks were from Qiagen (Valencia, CA). AeraSeal gas permeable sealing tape (T-2421-50) was from ISC Bioexpress (Kaysville, UT).

Plasmids

Genes were cloned into the expression vectors pVP56 and pVP62 $[32,33]$ using the Flexi Vector system (Promega,
Madison WI). Vector pVP56 yields a TEV protease cleavable His8-maltose binding protein (His-MBP) fused to the N-terminus of the protein target. Vector pVP62 yields an MBP fusion that can undergo in vivo proteolysis to liberate a His8-tagged target protein. Selection during cloning was provided by substitution of the gene of interest for the toxic insert of barnase and chloramphenicol acetyltransferase bounded by the SgfI and PmeI restriction sites. Plasmids containing the lethal barnase gene must be propagated in a barnase-resistant strain (e.g., Escherichia coli BR610, which is available through Technical Services, Promega Corporation).

Expression vector for in vivo proteolysis

Figure 1 shows a map of the CESG expression vector pVP62K. The vector produces an MBP-TVMV-His8-TEVtarget fusion, where MBP represents maltose binding protein, TVMV represents a tobacco vein mottling virus protease recognition site, and where TEV represents a tobacco etch virus protease recognition site. Genes are cloned into the SgfI and PmeI restriction sites that bound the Bar-CAT cassette. Self-ligation of the vector through the SgfI and PmeI sites is reduced by the inclusion the $3^{\prime}$ homology region [32], which is uniquely bounded by PmeI and HindIII restriction sites. LacI is expressed from this vector under control of the natural lac promoter [35]. The vector reserves the AvrII and BsiWI restriction sites to define an antibiotic resistance cassette so that the kanamycin resistance gene and promoter can be swapped with other antibiotic resistance genes and promoters. The vector also provides weak constitutive expression of TVMV protease under control of the tet promoter [33]. The LacI, kanamycin nucleotidyltransferase, and TVMV protease coding regions all have a $3^{\prime}$ transcriptional terminator to inhibit read-through expression.

The pRARE2 plasmid for rare codon supplementation was isolated from E. coli Rosetta2 cells (EMD Biosciences/Novagen) using a Qiagen miniprep kit.

\section{Primer design}

The DNA (GCG, Madison, WI) and Lasergene (DNAStar, Madison, WI) software were used to design and assemble primers used for PCR and sequencing. Overlap extension PCR [34] was used to synthesize a gene for green fluorescent protein (GFP) with $E$. coli codon optimization and the F64L, S65T, R81Q, F99S, M153T, and V163A mutations [36-38]. "One pot" recursive PCR was used to carry out de novo synthesis of the GFP gene [39-41]. Ten ssDNA primers with lengths of $90-95$ bases (Table 1) 

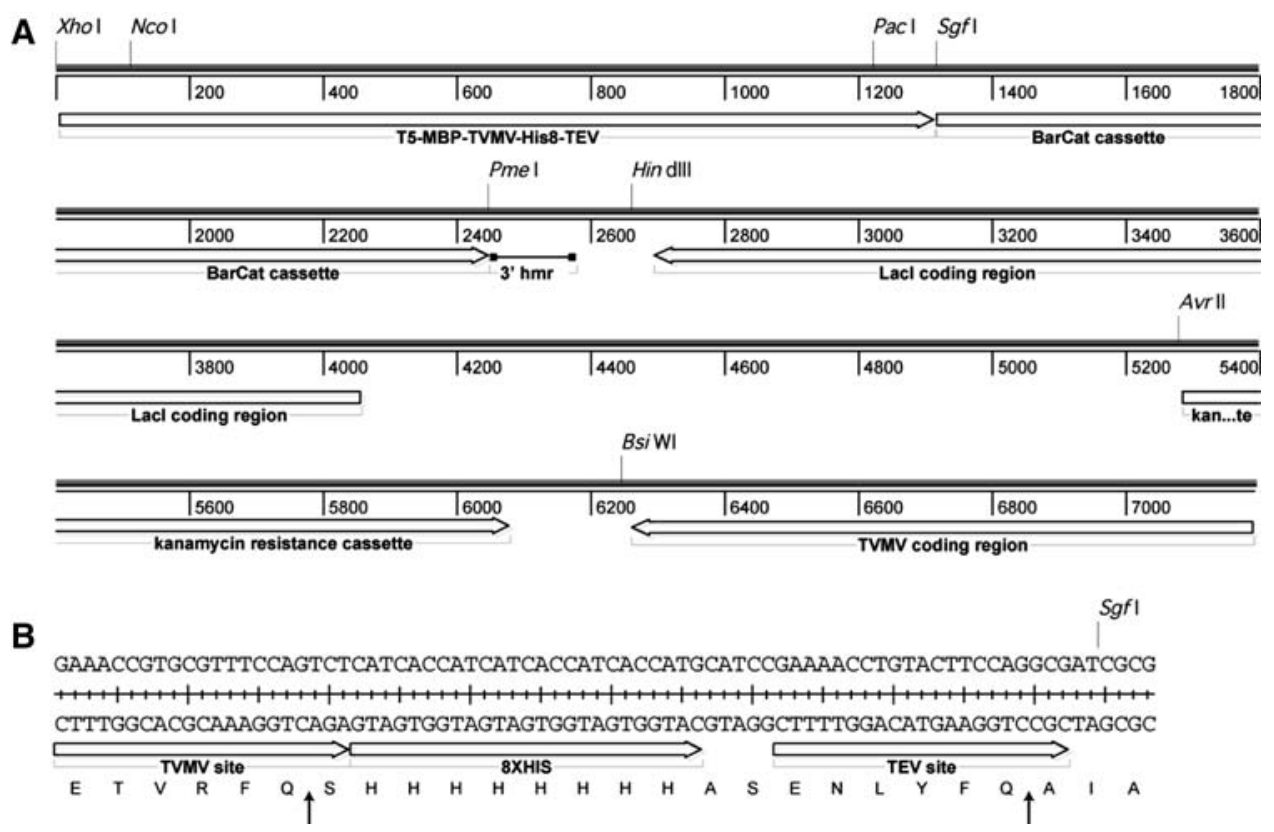

Fig. 1 Expression vector pVP62K. (a) Linear map showing key features of the vector and location of the Bar-CAT toxic cassette and $3^{\prime}$ homology region $\left(3^{\prime}\right.$-hmr) for Flexi Vector cloning. (b) Nucleotide and encoded protein sequence in the linker region near to the SgfI cloning site. The TVMV protease site is ETVRFQS, where proteolysis occurs between the $\mathrm{Q}$ and $\mathrm{S}$ residues. The fusion protein may be

were designed based on the coding and non-coding DNA strands so that $\sim 20$ bases at their ends overlapped with the adjacent primers and could be extended during the recursive PCR cycles. The eight internal primers (2-9 in Table 1) were used at a concentration of $0.25 \mathrm{pM}$, and each of the flanking primers $(1,10$ in Table 1$)$ were used at $50 \mathrm{pM}$. The recursive PCR conditions were as follows: $80^{\circ} \mathrm{C}$ for $5 \mathrm{~min}$; then 30 cycles of $94^{\circ} \mathrm{C}$ for $45 \mathrm{~s}, 55^{\circ} \mathrm{C}$ for $1 \mathrm{~min}$, and $72^{\circ} \mathrm{C}$ for $1 \mathrm{~min}$; and a final extension step of $72^{\circ} \mathrm{C}$ for $20 \mathrm{~min}$. PCR was performed using Deep Vent DNA polymerase (New England Biolabs, Ipswich, MA) on an MJ Research (Waltham, MA) Peltier Thermal Cycler.

The synthesized gene was purified using a Qiagen PCR purification kit (Valencia, CA), digested with NdeI (New England BioLabs) and BamHI (Promega) restriction enzymes, and ligated into similarly digested pET9a (EMD Biosciences/Novagen, Madison, WI) using standard molecular biology techniques [42]. The cloned GFP gene was subsequently used as a template for PCR amplification to prepare the GFP gene for Flexi Vector cloning into pVP62K [32, 33].

\section{Bacterial expression strain}

The methionine auxotroph $E$. coli $\mathrm{B} 834$ (genotype $\mathrm{F}^{-}$ompT $\mathrm{hsdS}_{\mathrm{B}}\left(\mathrm{r}_{\mathrm{B}}^{-} \mathrm{m}_{\mathrm{B}}^{-}\right)$gal dem met, [43, 44]) was transformed with cleaved in the expression host due to the presence of a low level of TVMV protease produced by constitutive expression from $\mathrm{pVP} 62 \mathrm{~K}$. The TEV protease site is ENLYFQA, where proteolysis occurs between the $\mathrm{Q}$ and $\mathrm{A}$ residues. After purification of the His8-tagged protein, the His 8 tag can be removed by treatment with TEV protease to release an N-terminal AIA-target

pRARE2 and used for either selenomethionine or ${ }^{15} \mathrm{~N}$ labeling [28, 29].

\section{Proteins investigated}

Table 2 summarizes the proteins investigated in this work. For some proteins, results from studies using a previously described pipeline are included [29, 30].

Cell growth, protein production, and cell lysis

The methods for bacterial growth, protein production, and analysis were described elsewhere [28-30]. For the ${ }^{15} \mathrm{~N}$ labeling in the auto-induction medium [28], ${ }^{15} \mathrm{~N}$ Celtone liquid (Spectra Stable Isotopes, Columbia, MD) was added $(5 \% \mathrm{v} / \mathrm{v})$ to stimulate protein expression.

Target genes were screened for production at the small-scale $(0.4 \mathrm{ml})$ in 96-well growth blocks using an auto-induction medium modified from the original [45] to better match correlation between small- and large-scale production [33]. Meso-scale cell cultures $(10-50 \mathrm{ml})$ for structural studies were grown as replicates in the 96-well growth blocks or in 0.51 baffled shaking flasks $(50 \mathrm{ml}$ of medium per flask). Cells were grown for $24 \mathrm{~h}$ at $25^{\circ} \mathrm{C}$ with shaking at $\sim 250 \mathrm{rpm}$ on a microplate shaker (VWR, 
Table 1 Alternating coding and non-coding strand PCR primers used for construction of an optimized GFP gene

\begin{tabular}{|c|c|c|}
\hline Primer & Length & Nucleotide sequence $^{\mathrm{a}}$ \\
\hline 1 & 90 & $\begin{array}{l}\text { CCCCCGGGGGCCCATATGTCCAAAGGTGAAGAACTGTTCACCGGTGT } \\
\text { TGTTCCGATCCTGGTTGAACTGGACGGTGACGTTAACGGTCAC }\end{array}$ \\
\hline 2 & 95 & $\frac{\text { CTGCCACTGCAATTGCCAGTGTTTAAGAGGCAAAGGCCACTTCCAC }}{\text { TTCCACTGCGATGGATGCCATTTGACTGGGACTTTAAGTAGACGTGGTG }}$ \\
\hline 3 & 94 & $\begin{array}{l}\frac{\text { CCTGAAATTCATCTGCACCACCGGTAAACTGCCGGTTCCGTGGCCG }}{\text { ACCCTGGTTACCACCCTGACCTACGGTGTTCAGTGCTTCTCCCGTTAC }} \\
\end{array}$ \\
\hline 4 & 95 & $\frac{\text { CAAGTCACGAAGAGGGCAATGGGCCTGGTGTACTTTGTCGT }}{\text { GCTGAAGAAGTTTAGGCGATACGGCCTTCCAATGCAAGTCCTTGCATGGTAGAG }}$ \\
\hline 5 & 94 & $\frac{\text { CGTTCAGGAACGTACCATCTCCTTCAAAGACGACGGTAACTACAAAACCCG }}{\text { TGCTGAAGTTAAATTCGAAGGTGACACCCTGGTTAACCGTATC }}$ \\
\hline 6 & 94 & $\frac{\text { CTGTGGGACCAATTGGCATAGCTTGACTTTCCATAGCTGAAGTTTC }}{\text { TTCTGCCATTGTAGGACCCAGTGTTTGACCTTATGTTGATGTTGAGGG }}$ \\
\hline 7 & 92 & $\frac{\text { GGAATACAACTACAACTCCCACAACGTTTACATCACCGCTGAC }}{\text { AAACAGAAAAACGGTATCAAAGCTAACTTCAAAATCCGTCACAACATCG }}$ \\
\hline 8 & 94 & $\frac{\text { GTTTTAGGCAGTGTTGTAGCTTCTGCCAAGGCAAGTCGACCGACTGGTGATGG }}{\text { TCGTCTTGTGGGGCTAGCCACTGCCAGGCCAAGACGACGGC }}$ \\
\hline 9 & 94 & $\frac{\text { GACGGTCCGGTTCTGCTGCCGGACAACCACTACCTGTCCACCCAGTCCGC }}{\text { TCTGTCCAAAGACCCGAACGAAAAACGTGACCACATGGTTCTGC }}$ \\
\hline 10 & 90 & $\frac{\text { GCACTGGTGTACCAAGACGACCTTAAGCAATGGCGACGACCATAGTGGGTGC }}{\text { CATACCTGCTTGACATGTTTATTCGAACCTAGGGCCCC }}$ \\
\hline
\end{tabular}

\footnotetext{
a The underlined DNA sequences are the overlapping complementary annealing segments used to assemble the synthetic codon optimized GFP gene. Primers numbered 1 (containing an NdeI site in bold) and 10 (with a Bam HI site in bold) are the flanking oligonucleotides at the beginning and end of the gene, respectively
}

West Chester, PA). After completion of the auto-induction protocol, bacterial cell cultures were harvested by centrifugation at $4,000 \mathrm{rpm}$ and $4^{\circ} \mathrm{C}$ for $10-15$ min using either an Allegra 6R centrifuge with a GH3.8 rotor or an Avanti J30-I with a JS5.9 rotor (Beckman Coulter, Fullerton, CA).

The pelleted cells were suspended in $8 \mathrm{ml}$ of lysis buffer containing $50 \mathrm{mM} \mathrm{NaH}{ }_{2} \mathrm{PO}_{4}, \mathrm{pH} 7.4,0.5 \mathrm{M} \mathrm{NaCl}, 20 \%$ (w/v) ethylene glycol, and $1 \mathrm{mg} / \mathrm{ml}$ lysozyme (EMD Biosciences/Novagen). Protease inhibitors (E-64, $1.0 \mu \mathrm{M}$, Sigma, St. Louis, MO; benzamidine, $0.5 \mathrm{mM}$, Calbiochem, La Jolla, CA) were added to the cell suspension. A second lysis buffer was used for meso-scale $(50 \mathrm{ml})$ protein production and contained $50 \mathrm{mM}$ HEPES, $\mathrm{pH} 7.5$, and $1 \mathrm{mg} /$ ml lysozyme, E-64 protease inhibitor mix, and 10 units Benzonase (EMD Biosciences/Novagen). The suspended cells were sonicated using a Misonix 3000 sonicator (Misonix, Farmingdale NY) using $10 \mathrm{~s}$ sonication pulses for a total of $4 \mathrm{~min}$ with $30 \mathrm{~s}$ rest intervals between pulses.

Protein production analysis by denaturing electrophoresis

Samples for total protein production analysis were prepared for LabChip90 capillary electrophoresis (Caliper Life Sciences, Hopkinton, MA) as recommended by the manufacturer and were prepared for SDS-PAGE analysis using Criterion SDS-PAGE polyacryalmide gels (4-20\% gradient Tris- $\mathrm{HCl}, 1.0 \mathrm{~mm}, 26$ comb, BioRad, Richmond
CA) as previously reported [29]. The soluble protein fraction was obtained by centrifuging the sample plates for $30 \mathrm{~min}$ at $2,200 \times \mathrm{g}$. Produced protein levels were determined by LabChip90 analysis and fluorescence (AIAGFP). SDS- PAGE gels were analyzed using the Fotodyne Imaging System (Fotodyne Inc, Hartland, WI) and Foto/ Analyst PC Image version 5.0 software.

Maxwell 16 purification screening protocol

For small-scale protein purification screening using the Maxwell 16 system, E. coli B834-pRARE2 cells were grown and genes expressed in isotopically enriched autoinduction medium using 96-well growth blocks. The growth was continued for $24 \mathrm{~h}$ until the culture had reached saturation, and then the culture was harvested by centrifugation $(2,500 \mathrm{rpm}$ for $2 \mathrm{~min})$. The initial autoinduction growth medium was removed, and the cells were re-suspended by vortexing with $50 \mathrm{mM}$ HEPES, $\mathrm{pH} 7.5$, containing a protease inhibitor cocktail [30] to give an $\mathrm{OD}_{600}$ of 20 in $1 \mathrm{ml}$.

The vendor's protocol and instructions were followed for protein purification. First, the Maxwell 16 protein purification cartridges were placed into the preparation rack. The cartridge seals were removed, and one plunger was placed into well \#7 of each cartridge. An elution tube was placed for each protein sample into the front of the platform, and $300 \mu \mathrm{l}$ of elution buffer was added to each 
Table 2 Structural genomics target proteins investigated

\begin{tabular}{|c|c|c|c|c|c|c|c|c|}
\hline \multirow[t]{2}{*}{ Lane $^{a}$} & \multirow[t]{2}{*}{ Protein $^{\mathrm{b}}$} & \multirow[t]{2}{*}{ Mol. wt. (Da) } & \multirow[t]{2}{*}{ pI } & \multicolumn{2}{|c|}{ Original pipeline $^{c}$} & \multicolumn{2}{|c|}{ Purification screen $^{\mathrm{d}}$} & \multirow[t]{2}{*}{ Better prediction $^{\mathrm{e}}$} \\
\hline & & & & Score & Decision & $\mu \mathrm{g} / \mathrm{ml}$ & Decision & \\
\hline A1 & Homo sapiens MGC:16774 & $51,892.0$ & 6.9 & MMH & Purify & 883 & Purify & \\
\hline A2 & Homo sapiens MGC:120678 & $54,803.5$ & 9.5 & HHM & Purify & 0 & Work stopped & Yes \\
\hline A3 & Danio rerio MGC: 103638 & $56,755.3$ & 8.6 & MMM & Purify & 273 & Purify & \\
\hline A4 & Homo sapiens MGC:120778 & $57,037.5$ & 10.1 & HMW & Work stopped & 93 & Work stopped & \\
\hline A5 & Xenopus laevis MGC53931 & $69,328.8$ & 4.1 & MMM & Purify & 286 & Purify & \\
\hline A6 & Danio rerio MGC:110031 & $70,033.3$ & 9.4 & MMM & Purify & 36 & Work stopped & Yes \\
\hline A7 & Danio rerio MGC: 109975 & $74,013.6$ & 6.6 & WWW & Work stopped & 82 & Work stopped & \\
\hline A8 & Homo sapiens MGC:4153 & $78,593.1$ & 7.7 & WWW & Work stopped & 370 & Purify & $\mathrm{No}^{\mathrm{f}}$ \\
\hline A9 & Xenopus laevis MGC78998 & $79,989.0$ & 4.5 & MMW & Work stopped & 491 & Purify & $\mathrm{No}^{\mathrm{f}}$ \\
\hline A10 & Danio rerio MGC: 110849 & $79,337.4$ & 9.7 & HHM & Purify & 45 & Work stopped & Yes \\
\hline A11 & Danio rerio MGC:113305 & $79,916.3$ & 6.0 & HMM & Purify & 283 & Purify & \\
\hline A12 & Danio rerio MGC:110805 & $84,575.6$ & 4.8 & HMM & Purify & 394 & Purify & \\
\hline B1 & Mus musculus MGC:5775 & $84,058.9$ & 9.1 & MMM & Purify & 10 & Work stopped & Yes \\
\hline B2 & Danio rerio MGC:113187 & $84,420.4$ & 9.4 & MMW & Work stopped & 11 & Work stopped & \\
\hline B3 & His8-MBP & $44,000.0$ & 5.5 & nd & Purify & 361 & Purify & \\
\hline B4 & AIA-GFP & $29,225.0$ & 5.59 & HHH & Purify & 859 & Purify & \\
\hline
\end{tabular}

${ }^{a}$ Lane corresponding to the electropherogram image of Fig. 2. Lanes A1-B2 are His8-MBP-target fusion proteins expressed from pVP56 that cannot undergo in vivo cleavage. Lane B4 is His8-GFP expressed from pVP62 that can undergo in vivo cleavage

b Organism and mammalian gene collection identification number or control protein described in the text

c The three-letter score represents an assessment of protein production (first letter), solubility (second letter), and cleavage by TEV protease (third letter) with $\mathrm{H}$ indicating high expression, high solubility or high efficiency of proteolysis, $\mathrm{M}$ indicating intermediate behavior for these properties, and W indicating weak, unsuitable behavior. In our protocol "W" for any category is cause for "work stopped" on the target, while "H" or "M" scores advance a target to large-scale purification. Use of this quantification system has been published elsewhere [29]. In the original pipeline scoring, $65 \%$ of the targets gave the exact same result, and the remaining $35 \%$ had variations, primarily in the scores for solubility and proteolysis. The use of the in vivo cleavage vector pVP62 and purification screening (Figs. 3 and 4) addresses the issue of proteolysis as a part of the screening process by emphasizing the recovery of a purified protein rather than evaluation of intermediate steps

${ }^{\mathrm{d}}$ The $\mu \mathrm{g} / \mathrm{ml}$ reported for fusion proteins after automated purification using the Maxwell 16 was from the Caliper LC90 analysis. A yield of purified fusion protein greater than $100 \mu \mathrm{g} / \mathrm{ml}$ was used as the comparator for efficacy of the purification screening of His8-MBP fusion proteins

e Assessment of whether the Maxwell 16 purification would lead to better predictive behavior in small-scale screening. Entries marked "Yes" correspond to targets that would not advance to purification scale-up because they failed the automated Maxwell 16 purification

f Targets marked "No" would have been advanced to purification scale-up, but without an assessment of TEV proteolysis. Treatment of the Maxwell-purified fusion protein with TEV protease gave weak cleavage, as observed in the original pipeline screen. This weak cleavage behavior was reproduced in three additional samples produced in 21 growths. The use of the in vivo cleavage vector pVP62 (Figs. 3 and 4 ) addresses the issue of protease cleavage as part of the screening process

elution tube. Aliquots of the re-suspended cells were transferred into well \#1 of the Maxwell 16 purification cartridge, which also contained $10 \times$ Promega chemical lysis buffer, and the purification protocol was started. The Maxwell 16 system required $45 \mathrm{~min}$ to complete the purification run. The final purified proteins were removed from the elution cuvettes and analyzed by denaturing SDSPAGE using either BioRad Criterion SDS-PAGE gels (4$20 \%$ gradient Tris- $\mathrm{HCl}$ ) or the Caliper LC90 system.

\section{Purification of Tcl-1 for NMR studies}

A $50 \mathrm{ml}$ (meso-scale) overnight culture $\left(\mathrm{OD}_{600}\right.$ equal 10$)$ expressing Tcl-1 was harvested by centrifugation, and re-suspended in $\sim 10 \mathrm{ml}$ of $50 \mathrm{mM}$ HEPES $\mathrm{pH} 7.5$, with protease inhibitor cocktail [30], 10 units of Benzonase (EMD Biosciences/Novagen) to hydrolyze nucleic acids, and $1 \mathrm{mg} / \mathrm{ml}$ of lysozyme to reduce the viscosity of the lysate. The cell suspension was sonicated using a Sonic Dismembrator 550 (Fisher Scientific) programmed to run $10 \mathrm{~s}$ sonication pulses for a total of $5 \mathrm{~min}$ (with $20 \mathrm{~s}$ rest stops). Aliquots of the unclarified cell lysate $(1 \mathrm{ml})$ were applied to well \#1 of each lane of the Maxwell 16 cartridge, which also contained the chemical lysis buffer. The Maxwell 16 protocol for His-tagged proteins was run, and the purified His8-tagged protein samples from each lane were pooled. The final purified protein was exchanged into NMR screening buffer $\left(10 \mathrm{mM} \mathrm{KHPO}_{4}, 50 \mathrm{mM} \mathrm{KCl}, 0.2 \%\right.$ $\mathrm{NaN}_{3}, \mathrm{pH} 7.0$ ) and concentrated to a final volume of $0.5 \mathrm{ml}$ 
using Millipore Amicon filtration devices. The total yield of the $\left[U-{ }^{15} \mathrm{~N}\right]-\mathrm{Tcl}-1$ was $\sim 0.4 \mathrm{mg}$.

Purification of GFP for NMR and X-ray studies

A $50 \mathrm{ml}$ cell culture grown with auto-induction for $24 \mathrm{~h}$ $\left(\mathrm{OD}_{600}\right.$ equal to 10$)$ with the appropriate isotopic label was harvested by centrifugation, resuspended in $8-12 \mathrm{ml}$ of $50 \mathrm{mM}$ HEPES, $\mathrm{pH} 7.5$, with protease inhibitors, benzonase, and $1 \mathrm{mg} / \mathrm{ml}$ of lysozyme, and sonicated as above. Aliquots $(1 \mathrm{ml})$ of the unclarified cell lysate were applied to well \#1 of eight lanes of the Maxwell 16 cartridge prior to the purification run. $\left[U_{-}{ }^{15} \mathrm{~N}\right]-\mathrm{His} 8-\mathrm{GFP}$ and [Se-Met]labeled His8-GFP purified in this manner were each exchanged into the appropriate NMR [28] or X-ray [30] screening buffer, and concentrated to final volumes of $0.5 \mathrm{ml}$. The yield of the ${ }^{15} \mathrm{~N}$ labeled His8-GFP was $3.4 \mathrm{mg}$ from $50 \mathrm{ml}$ of cell culture. The purified [Se-Met]-His8GFP was treated subsequently with TEV protease [46] to remove the His8 tag; the His8 tag and His8-tagged TEV protease were removed by treatment with MagneHis particles; the buffer was exchanged, and the purified protein was concentrated to a final volume of $0.5 \mathrm{ml}$. The yield of selenomethionine labeled AIA-GFP was $2.8 \mathrm{mg}$.

\section{Protein characterization}

Purified proteins were analyzed by denaturing electrophoresis in the buffer described above. Concentrations were determined using the Caliper LC90 software and the BCA method (Pierce, Rockford IL). The masses of the purified $\left[U_{-}{ }^{15} \mathrm{~N}\right]-$ and [Se-Met]-labeled proteins were determined in the University of Wisconsin Biotechnology Center by electrospray ionization mass spectrometry using an Applied Biosystems/MDS Sciex API 365 LC/MS/MS triple quadrupole mass spectrometer (Applied Biosystems, Foster City, CA, USA). The labeling efficiency was calculated from the experimentally determined and calculated molecular weights of the protein. Protein identification was carried out by tryptic proteolysis and molecular weight assignment of generated peptides using a Bruker BIFLEX III MALDI-TOF spectrometer (Bruker Daltonics, Billerica, MA, USA).

\section{${ }^{1} \mathrm{H}-{ }^{15} \mathrm{~N}$ HSQC NMR}

2D ${ }^{1} \mathrm{H}-{ }^{15} \mathrm{~N}$ HSQC spectra were acquired for $\left[U_{-}{ }^{15} \mathrm{~N}\right]-$ labeled Tcl-1 and $\left[U_{-}{ }^{15} \mathrm{~N}\right]$-labeled GFP at the National Magnetic Resonance Facility at Madison (NMRFAM) on 600 and $750 \mathrm{MHz}$ Bruker spectrometers equipped with cryogenic ${ }^{1} \mathrm{H},{ }^{15} \mathrm{~N},{ }^{13} \mathrm{C}$ triple-resonance probes. The sample temperature was regulated at $35^{\circ} \mathrm{C}$. The NMR spectra consisted of 1,024 and 100-110 complex data points, respectively for ${ }^{1} \mathrm{H}$ and ${ }^{15} \mathrm{~N}$. For each increment, 128 scans were used for $\left[U-{ }^{15} \mathrm{~N}\right]$-labeled Tcl-1, and 16 scans were used for $\left[U_{-}{ }^{15} \mathrm{~N}\right]$-labeled GFP.

\section{Crystallization of AIA-GFP}

AIA-GFP was screened initially using the UW192 screen. From this screen, crystals were observed within 2 days from five different conditions. One condition was optimized for structure determination.

AIA-GFP crystals were grown by hanging drop vapor diffusion. The crystals reached a size of $\sim 0.1 \times 0.1 \times 1 \mathrm{~mm}$ rods in approximately 3 days at $25^{\circ} \mathrm{C}$ in a mother liquor consisting of $100 \mathrm{mM}$ HEPPS, $\mathrm{pH}$ $8.5,80 \mathrm{mM} \mathrm{CaCl}$, and $15 \%$ PEG $4 \mathrm{~K}$. Hanging drops consisted of $2.5 \mu \mathrm{l}$ of protein solution and $2.5 \mu \mathrm{l}$ of mother liquor. Crystals were soaked in mother liquor containing increasing amounts of glycerol to a final concentration of $20 \%$ and flash cooled in a stream of liquid nitrogen. X-ray diffraction data were collected on a BrukerAXS PROTEUM R (BrukerAXS, Madison, WI) diffractometer at $180^{\circ} \mathrm{C}$ using $\mathrm{CuK} \alpha$ radiation from a MicroStar (BrukerAXS, Madison, WI) source with a rotating anode generator operated at $44 \mathrm{kV}$ and $45 \mathrm{~mA}$. The X-ray data were processed and scaled with PROTEUM 2 (BrukerAXS, Madison, WI). The structure of GFP was solved by molecular replacement using PDB $2 \mathrm{~g} 6 \mathrm{e}$ as the rotation target with MOLREP from the CCP4 suite [47]. The model was built with alternating cycles of model building and refinement with COOT [48] and REFMAC [49]. Coordinates and structure factors were deposited in the Protein Data Bank with accession number 2 qu1.

\section{Results}

Met auxotrophy in E. coli B834

The strain E. coli B834 is frequently used for selenomethionine labeling [50]. It is a conditional methionine auxotroph that can be complemented by the addition of vitamin $\mathrm{B}_{12}$. The exact cause of the auxotrophy was not known, but some believed that MetB was inactive [43], while others thought that MetE was [45]. To better define the origin of the auxotrophy, genomic DNA was isolated, and the regions around the metE gene (GeneBank accession number DQ267751, encoding vitamin $\mathrm{B}_{12^{-}}$ independent homocysteine transmethylase) and the metH gene (GeneBank accession number DQ272318, encoding 
A
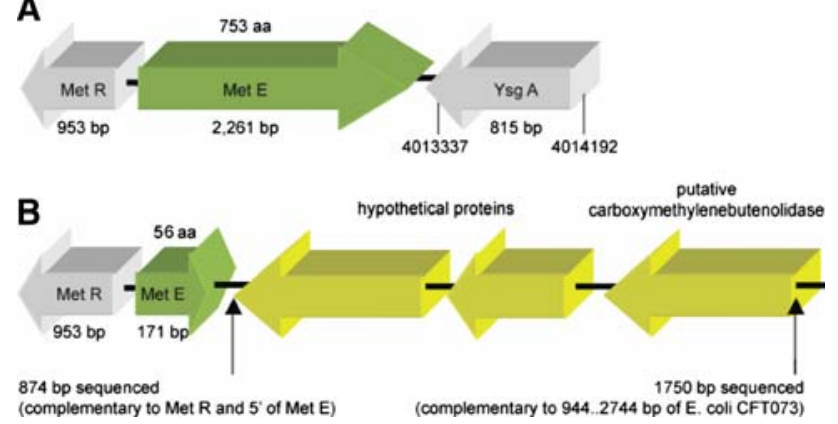

Fig. 2 Conditional methionine auxotrophy in E. coli B834. (a) Genome organization near to the metE gene in E. coli K12 [51]. (b) Genome organization near to the metE gene in E. coli B834. In this organism, DNA sequencing revealed a large insert in the metE gene, which caused the protein to be truncated to 56 amino acids (aa), non-functional peptide

vitamin $\mathrm{B}_{12}$-dependent homocysteine transmethylase) were sequenced.

Figure 2 shows the genome arrangement near to the metE gene in $E$. coli $\mathrm{K} 12$ (capable of growth in the absence of vitamin $\mathrm{B}_{12}$ ) and E. coli B834. DNA sequencing revealed that E. coli $\mathrm{B} 834$ metE was truncated from 753 amino acids to an inactive 56-residue peptide by insertion of a premature stop codon (TGA) and a DNA sequence with homology to several genes previously identified from the uropathogen E. coli CFT073 [52]. By contrast, the sequence of the metH gene in E. coli B834 was intact and matched (data not shown) the E. coli $\mathrm{K} 12$ gene [51]. Thus methionine auxotrophy in E. coli B834 arises from disruption of the metE gene.

\section{Proteins studied}

Table 1 summarizes the primers used to synthesize the modified GFP used in these studies. Other genes used in this work were cloned as previously described [32], and their properties are summarized in Tables 2 and 3. Results from small-scale expression screening using a previously described pipeline $[29,30]$ are included in Table 2, where the score is an assessment of expression, solubility of the fusion protein, and the ability of TEV protease to release the target from the fusion protein. For example, human MGC:16774 from lane A1 has a score of MMH for medium protein production, medium solubility, and high protease cleavage. By this assessment, this protein would be suitable for purification scale-up. In contrast, human MGC:120778 from lane A4 has a score HMW for high production, medium solubility, and weak protease cleavage. This protein would not be suitable for purification scale-up, because according to this protocol as any score of W leads to "work stopped".

\section{Maxwell 16 purification screening}

Figure 3 shows the results of small-scale production and purification of 14 different proteins from humans, frog, mouse, and zebra fish as analyzed by Caliper LC90 electrophoresis. The different proteins were produced in factorial evolved auto-induction medium with selenomethionine [33]. The sizes of the fusion proteins ranged from $54 \mathrm{kDa}$ to $86 \mathrm{kDa}$, and matched within $\pm 20 \%$ of those calculated from the gene sequences. The purity of the MBP fusions ranged from $30 \%$ to $100 \%$ as estimated by the capillary electrophoresis. The automated Caliper LC90 system also gave protein concentration estimates that were in agreement with the manual BCA assays.

Of the 14 fusion proteins tested (A1-B2, Table 2 and Fig. 3), seven were purified with yields exceeding $100 \mu \mathrm{g} /$ $\mathrm{ml}$, six were purified with yields less than $100 \mu \mathrm{g} / \mathrm{ml}$, and one protein was not purified. Among the seven high yield proteins, five also received a favorable assessment for scale-up by the original scoring method; among the six low yield proteins, three also received an unfavorable assessment for scale-up by the original scoring method. Thus the decision to scale-up the purification or not was the same by either method in eight of 14 cases.

Among the six proteins that were assessed differently by the original method and the newer purification screening,

Table 3 Human embryonic stem cell proteins and others characterized by in vivo cleavage and purification screening

\begin{tabular}{lllll}
\hline Protein $^{\mathrm{a}}$ & Annotation & Database ID & Mol. wt. (Da) & Yield $(\mu \mathrm{g} / \mathrm{ml})^{\mathrm{b}}$ \\
\hline$\left[U{ }^{15} \mathrm{~N}\right]-$ His8-Tcl-1 & T-cell leukemia/lymphoma & MGC:20335, 2260, 2170 & $13,459.6$ & 7.5 \\
CCNF & Cyclin F & MGC:20163 & $87,639.8$ & $<1$ \\
C10orf96 & Chromosome 10 open reading frame 96 & MGC: 35062 & $31,035.3$ & Not detected \\
NPM2 & Nucleophosmin/nucleoplasmin 2 & MGC:78655 & $24,152.0$ & $<1$ \\
{$\left[U-{ }^{15}\right.$ N]-His8-GFP } & Control protein, synthetic gene & & $26,842.4$ & 68 \\
SeMet-AIA-GFP & Control protein, synthetic gene & & $29,226.0$ & 172 \\
\hline
\end{tabular}

${ }^{a}$ cDNA for the human proteins provided by Prof. James Thomson

b From Caliper LC90 analysis of the protein obtained from Maxwell 16 purification 


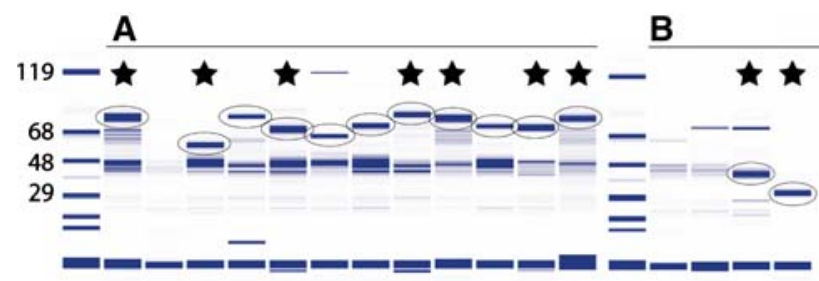

LA A1 A2 A3 A4 A5 A6 A7 A8 A9 A10 A11 A12 LB B1

Fig. 3 Caliper LC90 analysis of His8-tagged proteins purified by Maxwell 16. Lanes LA and LB are molecular weight markers. Lanes A1-B2 are structural genomics target proteins (protein bands marked with ovals) with molecular weight $\sim 50-75 \mathrm{kDa}$. They were expressed in factorial evolved auto-induction medium containing selenomethionine [33] as an N-terminal fusion with MBP from pVP56K, a vector that does not give in vivo proteolysis of the fusion protein. Lane B3 contains His8-MBP (protein band marked with oval), while lane B4 $(1.1 \mathrm{mg} / \mathrm{ml})$ contains His8-GFP expressed from pVP62 after in vivo cleavage from MBP. Lanes with a purified expressed fusion protein with yield than $100 \mu \mathrm{g} / \mathrm{ml}$ are marked with a star (also see Table 2 )

there were two outcomes. One outcome, exemplified by $\mathrm{A} 2$, A6, A10, and B1, were proteins that had a favorable score by the original method, but that were not purified in yield $>100 \mu \mathrm{g} / \mathrm{ml}$ by the newer purification screening protocol. Use of purification screening would eliminate unnecessary scale-up effort for a class of proteins that ultimately fail in purification. The other outcome, exemplified by $\mathrm{A} 8$ and $\mathrm{A} 9$, was a successful purification of a large amount of protein when the work would have been stopped by the original method. Since the results of Fig. 3 with A8 and A9 do not include a proteolysis step, the original screen provided additional information suggesting that these targets would ultimately fail in purification because they had an unsuitable $\mathrm{W}$ score for proteolysis. Indeed, when A8 and A9 obtained from the Maxwell were treated with TEV protease, neither target was successfully liberated from the fusion protein.

In order to address this deficiency in the purification screening, we developed an in vivo cleavage expression vector to couple with the Maxwell 16 purification system. The assembly of this vector and results of using this combination for purification screening of human embryonic stem cell proteins is described in the following sections.

Purification screening of human stem cell proteins

Table 3 identifies the four human stem cell proteins studied and Fig. 4 shows the results of Maxwell 16 purification for the human proteins and AIA-GFP that were expressed from the in vivo cleavage plasmid pVP62K. As judged by the appearance of a prominent protein band from the

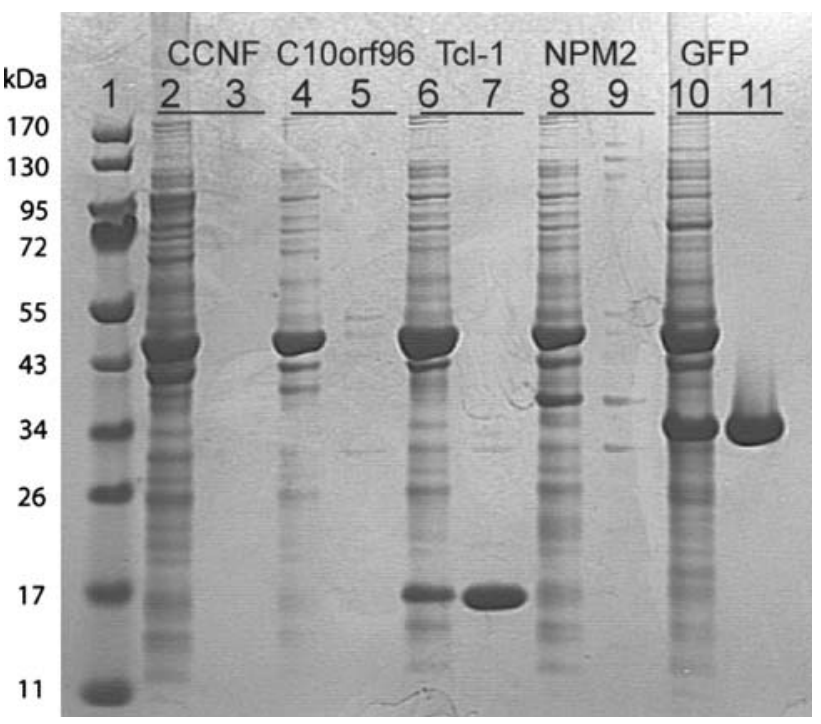

Fig. 4 Small-scale purification screening of human embryonic stem cell proteins. Human stem cell proteins were expressed in E. coli B834 by auto-induction, liberated by in vivo proteolysis, and purified by the Maxwell 16 purification system. Table 2 provides further information on these proteins. Lane 1, molecular weight markers. Lanes 2 and 3, total cell lysate and eluted sample from purification of CCNF. No purified protein was detected. Lanes 4 and 5, C10orf96 was obtained in detectable amounts, but not sufficient for scale-up, along with two higher molecular weight contaminants. Lanes 6 and 7 , His8-Tcl-1 was expressed, proteolyzed, and successfully purified. Lanes 8 and 9, NPM2 was expressed and proteolyzed, but only a small amount of protein was purified. In addition, the purified protein appeared to be partially degraded. Lanes 10 and 11, His8-GFP

in vivo proteolyzed MBP, the auto-induction process was successfully executed for all five proteins. However, only human embryonic stem cell T-cell lymphoma-1 (Tcl-1, lane 7) and AIA-GFP (lane 11) were successfully purified in large quantities. Two other stem cell proteins were apparently purified in small quantities (C10orf96 and NPM2, lanes 5 and 9, respectively), but not in sufficient amounts for scale-up.

\section{Replicate Maxwell 16 purification of Tcl-1}

The number of replicate Maxwell 16 lanes required to purify sufficient $\left[U{ }_{-}{ }^{15} \mathrm{~N}\right]$-His8-Tcl-1 protein for ${ }^{1} \mathrm{H}-{ }^{15} \mathrm{~N}$ HSQC measurements was estimated on the basis of the BCA quantification of the single lane results (Fig. 4, lane 7). Figure 5 shows the results of the repetitive purifications from a $50 \mathrm{ml}$ meso-scale cell culture. Each well held the cell lysate from the equivalent of $\sim 4 \mathrm{ml}$ of cell culture. The cell lysate was processed by a modification of the manufacturer's protocol as described in Materials and Methods. After the Maxwell 16 purification, the individual wells were pooled. The pooled sample was concentrated and exchanged into a buffer suitable for NMR studies. 


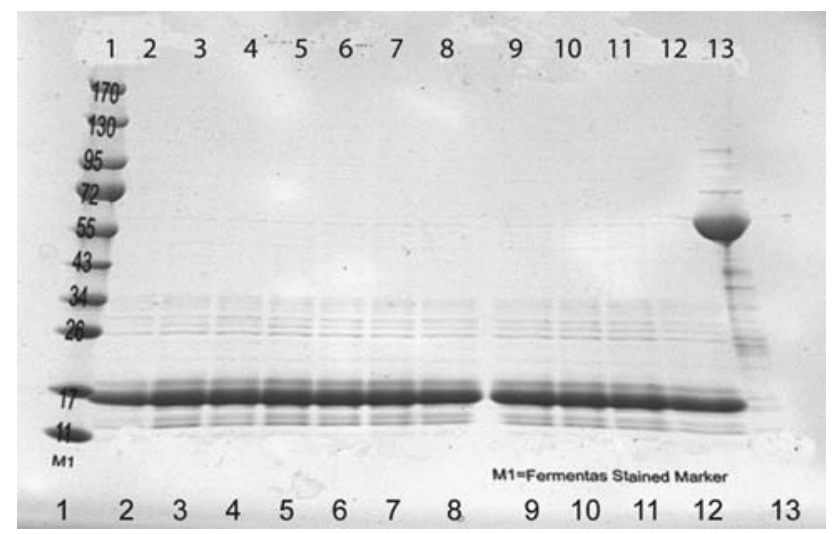

Fig. 5 Replicate Maxwell 16 purification of human embryonic stem T-cell lymphoma-1 protein. Lane 1, molecular weight markers. Lanes 2-12, replicate purifications of His8-Tcl-1. Lane 13, His8-MBPAt2g34690.1, an Arabidopsis thaliana protein expression control

These post-purification handling steps took $\sim 1.5 \mathrm{~h}$. In total, $\sim 0.4 \mathrm{mg}$ of pure $\left[\mathrm{U}_{-}{ }^{15} \mathrm{~N}\right]-\mathrm{His} 8-\mathrm{Tcl}-1$ protein was obtained. The percentage incorporation of ${ }^{15} \mathrm{~N}$ in purified His8-Tcl-1 was determined by electrospray ionization mass spectrometry to be greater than $95 \%$.

A similar scale-up of the initial expression results was undertaken for AIA-GFP (Fig. 4, lane 11) with either $\left[U_{-}{ }^{15} \mathrm{~N}\right]-$ or [Se-Met]-labeling. The expressed AIA-GFP had high fluorescence, and could be easily observed by visual inspection at all steps of the automated purification. The identity of purified AIA-GFP was confirmed by tryptic proteolysis and liquid chromatography/tandem mass spectrometry. The yield of $\left[U_{-}{ }^{15} \mathrm{~N}\right]-\mathrm{His} 8-\mathrm{GFP}$ was $\sim 3.4 \mathrm{mg}$. This sample was pooled and concentrated, and further exchanged into a buffer suitable for NMR studies $(\sim 2 \mathrm{~h})$. For X-ray crystallography, the His8-tag was removed by treatment with TEV protease. The final yield of purified AIA-GFP was $2.8 \mathrm{mg}$, and a high level of selenomethionine was incorporated into the purified AIA-GFP as determined by electrospray ionization mass spectrometry.

\section{NMR characterization}

Figure 6a shows the $750 \mathrm{MHz}{ }^{1} \mathrm{H}_{-}-{ }^{15} \mathrm{~N}$ HSQC spectrum of His8-Tcl-1. This spectrum was acquired in $9.5 \mathrm{~h}$. The HSQC spectrum of His8-Tcl-1 is characteristic of a folded protein [28]. Including cross peaks from the Asn, Gln and Trp sidechains and excluding the flexible N-terminal Histag and TEV protease site, 102 out of the possible 117 cross peaks for the native protein were present. The favorable peak count and the observed chemical shift dispersion indicate that His8-Tcl-1 is amenable for NMR structural analysis [28].

Figure $6 \mathrm{~b}$ shows the $600 \mathrm{MHz}{ }^{1} \mathrm{H}-{ }^{15} \mathrm{~N}$ HSQC NMR spectrum of His8-GFP recorded at $25^{\circ} \mathrm{C}$. This spectrum
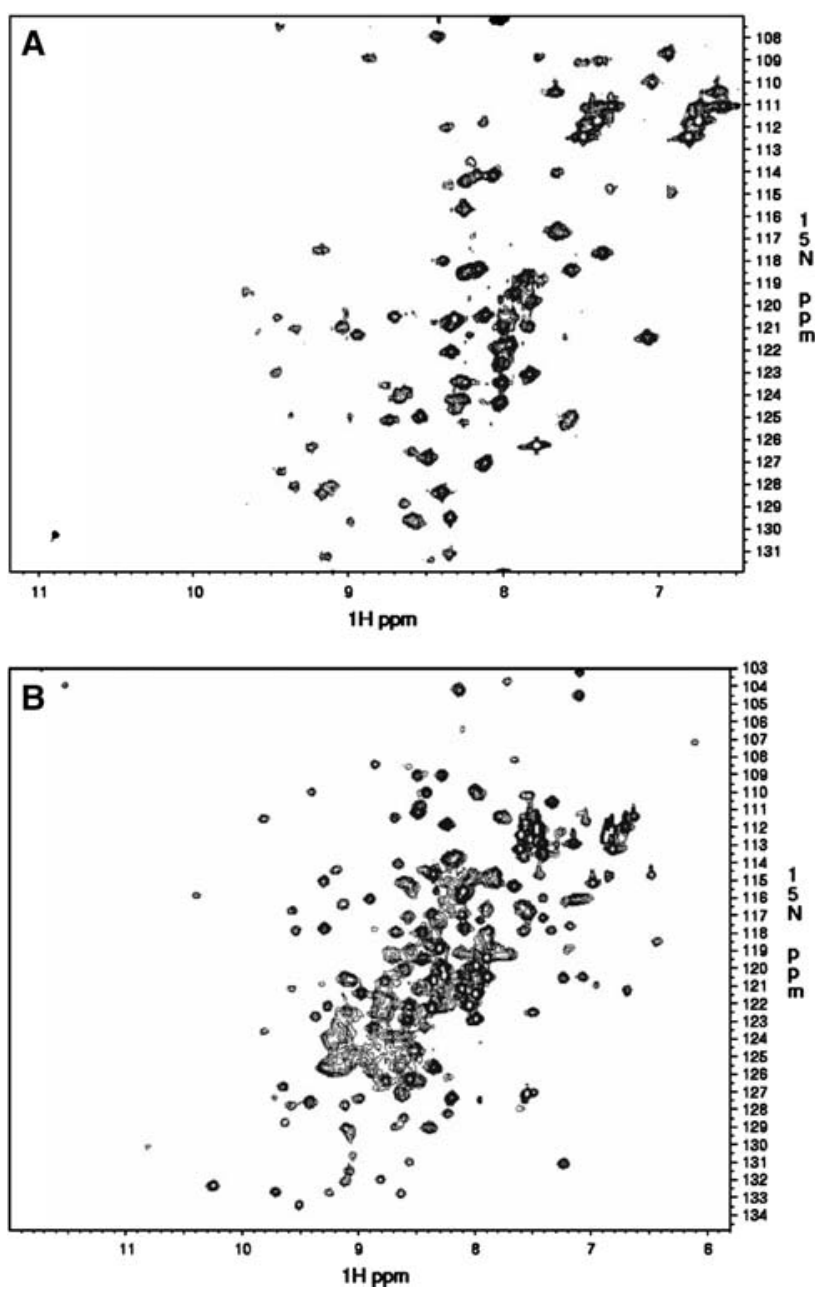

Fig. $6{ }^{1} \mathrm{H}-{ }^{15} \mathrm{~N}$ HSQC NMR spectra of Maxwell-purified proteins Tcl-1 and GFP. (a) $750 \mathrm{MHz}$ spectrum of His8-Tcl-1 obtained at $35^{\circ} \mathrm{C}(1.75 \mathrm{mg}$ in $250 \mu \mathrm{l}$ of $10 \mathrm{mM} \mathrm{KHPO} 4, \mathrm{pH} 7$, containing $50 \mathrm{mM}$ $\mathrm{KCl})$. The total NMR time required to obtain this spectrum was $9.5 \mathrm{~h}$. (b) $600 \mathrm{MHz}$ spectrum of His8-GFP obtained at $35^{\circ} \mathrm{C}(5.6 \mathrm{mg}$ in $250 \mu \mathrm{l}$ of $10 \mathrm{mM} \mathrm{KHPO}_{4}, \mathrm{pH} \mathrm{7}$, containing $50 \mathrm{mM} \mathrm{KCl}$ ). The total NMR time required to obtain this spectrum was $1 \mathrm{~h}$

was acquired in $1 \mathrm{~h}$. For this GFP, a total of about 219 cross peaks out of a possible 253 cross peaks (including amino acid chain amides) were present. The broader NMR line widths due to the larger size of GFP (238 aa, $\sim 27,000 \mathrm{Da}$ ) account for some the difference between the numbers of expected and observed cross peaks. Nevertheless, the chemical shifts are well dispersed, suggesting that the Maxwell-purified protein was well structured in solution and thus acceptable for further structural studies.

\section{X-ray structure of AIA-GFP}

The AIA-GFP was screened for crystallization using the UW192 crystallization screen. As AIA-GFP contained 
several surface mutations, and in addition, the N-terminal AIA sequence derived from the Flexi Vector cloning protocol [32], several unique crystallization conditions were identified by the crystallization screening. Table 4 shows the five conditions that gave crystals within 2 days.

Condition 4 was selected for optimization, and the resulting crystals diffracted well. The structure of GFP was solved by molecular replacement at a resolution of $1.7 \AA$. Table 5 shows data collection statistics and results of the structure determination, while Fig. 7 shows the structure of AIA-GFP. Interpretable electron density was observed from all residues of the protein. Consistent with this observation, the chromophore consisting of cross-linked residues T65, Y66, and G67 was clearly present in the refined structure. In total, this effort used $2.8 \mathrm{mg}$ of the protein provided from eight lanes of the Maxwell 16 purification system.

\section{Discussion}

Figure 8 shows a schematic workflow for purificationbased screening of expressed proteins. We have applied this approach to eukaryotic proteins, including those from human embryonic stem cells. The advantages of the approach include the small quantity of cell culture required, the speed in going from cells to purified protein, the relatively low cost of the procedure, the ability to scale up to automated, multiple-lane purifications, and the protein yields, which are sufficient to support characterization of the protein product.

\section{Purification screening}

Protein production pipelines have numerous points of attrition that limit the number of proteins available for structural analysis. This attrition adds significant expense to the overall process, particularly when multiple handling steps and larger volumes are typically required to obtain decisions. Thus the use of small- or micro-scale protein screening methods has considerable appeal [22, 24].

The focus of this work has been on eukaryotic proteins, which are generally found to be more difficult to express and purify than prokaryotic proteins. Small-scale
Table 5 Summary of data collection, crystal structure, and refinement statistics for AIA-GFP

\begin{tabular}{|c|c|}
\hline \multicolumn{2}{|l|}{ Data collection $^{\mathrm{a}}$} \\
\hline Space group & $\mathrm{P} 2{ }_{1} 2_{1} 2_{1}$ \\
\hline \multicolumn{2}{|l|}{ Cell dimensions } \\
\hline a, b, c $(\AA)$ & $51.46,61.99,70.02$ \\
\hline$\alpha, \beta, \gamma\left({ }^{\circ}\right)$ & $90,90,90$ \\
\hline Resolution $(\AA)^{\mathrm{b}}$ & $46.42-1.70(1.74-1.70)$ \\
\hline No. reflections & 23752 \\
\hline $\mathrm{R}_{\text {merge }}(\%)^{\mathrm{c}}$ & $15.7(36.6)$ \\
\hline$(\mathrm{I} / \sigma \mathrm{I})^{\mathrm{d}}$ & $28.27(2.93)$ \\
\hline Completeness $(\%)$ & $98.98(97.32)$ \\
\hline Redundancy & $29.45(5.42)$ \\
\hline \multicolumn{2}{|l|}{ Refinement $^{\mathrm{e}, \mathrm{f}}$} \\
\hline Resolution $(\AA)$ & $46.42-1.70(1.74-1.70)$ \\
\hline No. reflections & $23752(1276)$ \\
\hline $\mathrm{R}_{\text {work }} / \mathrm{R}_{\text {free }}$ & $0.168 / 0.220(0.246 / 0.323)$ \\
\hline \multicolumn{2}{|l|}{ No. atoms } \\
\hline Protein & $1915^{\mathrm{g}}$ \\
\hline Water & 377 \\
\hline Mean B-value (overall) & 12.34 \\
\hline \multicolumn{2}{|l|}{ Ramachandran analysis } \\
\hline Most favored regions & 92.4 \\
\hline Additional allowed regions & 7.6 \\
\hline \multicolumn{2}{|l|}{ RMS deviations } \\
\hline Bond lengths $(\AA)$ & 0.012 \\
\hline Bond angles $\left({ }^{\circ}\right)$ & 1.548 \\
\hline
\end{tabular}

${ }^{a}$ Data collected at University of Wisconsin Center for Eukaryotic Structural Genomics. Coordinates and structure factors were deposited in the Protein Data Bank with accession number 2qu1

b Numbers in parentheses indicate the highest resolution shell of 20

${ }^{\mathrm{c}} R_{\text {merge }}=\Sigma|I-\langle I\rangle| / \Sigma I$, where $I$ is the observed intensity and $\langle I\rangle$ is the average intensity obtained from multiple measurements

$\mathrm{d}$ The root-mean-squared value of the intensity measurements divided by their estimated standard deviation

${ }^{\mathrm{e}} R_{\text {work }}=\Sigma|| F_{0}|-| F_{\mathrm{c}}|| / \Sigma\left|F_{0}\right|$, where $\left|F_{0}\right|$ is the observed structure factor amplitude and $\left|F_{\mathrm{c}}\right|$ is the calculated structure factor amplitude

${ }^{\mathrm{f}} R_{\text {free }}=R$-factor based on $5.1 \%$ of the data excluded from refinement

$\mathrm{g}$ Number of non-hydrogen protein atoms included in refinement

production screening efforts have predicted the outcome of downstream large-scale protein production with up to $80 \%$ efficiency [26]. However, these previous efforts did not
Table 4 Summary of crystallization conditions observed for AIA-GFP

a Conditions present in the UW192 crystallization screen used at UW Center for Eukaroytic Structural Genomics

\begin{tabular}{llll}
\hline Condition $^{\mathrm{a}}$ & Precipitant (w/v) & Buffer & Salt \\
\hline 1 & 24\% MEPEG 5K & $0.1 \mathrm{M} \mathrm{MES,} \mathrm{pH} \mathrm{6.0}$ & $160 \mathrm{mM} \mathrm{CaCl}_{2}$ \\
2 & $16 \%$ MEPEG 5K & $0.1 \mathrm{M} \mathrm{BTP}, \mathrm{pH} 7.0$ & $200 \mathrm{mM} \mathrm{glycine}$ \\
3 & $28 \%$ MEPEG 2K & $0.1 \mathrm{M}$ HEPES, pH 7.5 & $100 \mathrm{mM} \mathrm{CaCl}_{2}$ \\
4 & $20 \%$ PEG 4K & $0.1 \mathrm{M} \mathrm{HEPPS,} \mathrm{pH} \mathrm{8.5}$ & $80 \mathrm{mM} \mathrm{CaCl}_{2}$ \\
5 & $60 \%$ MPD & $0.1 \mathrm{M} \mathrm{MES,} \mathrm{pH} \mathrm{6.0}$ & None \\
\hline
\end{tabular}




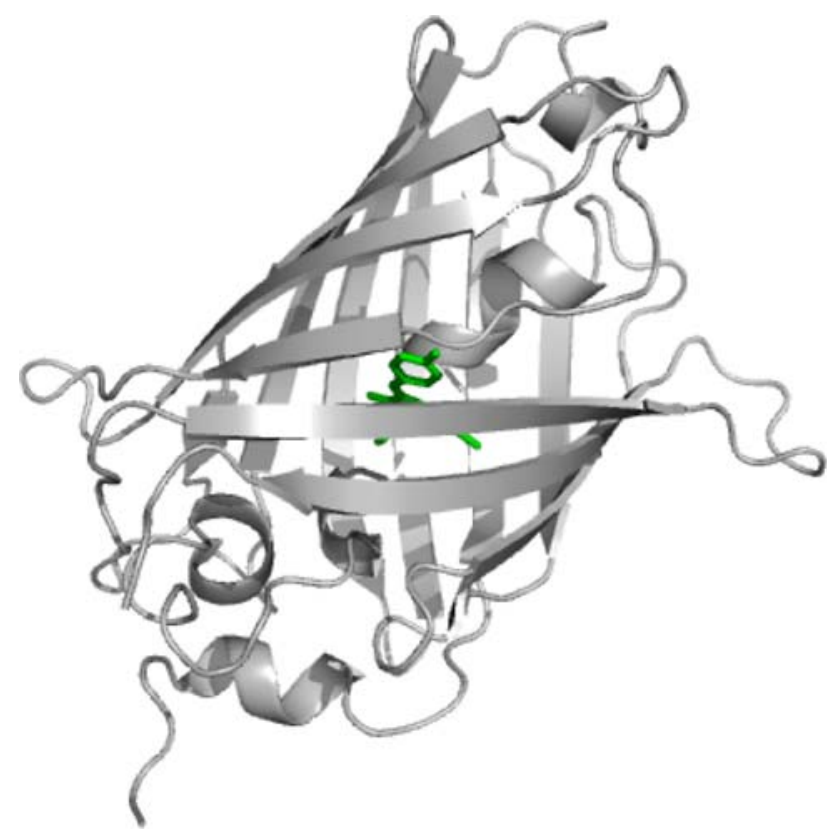

Fig. 7 X-ray structure of AIA-GFP. The chromophore is shown as green cylinders representing bonded atoms

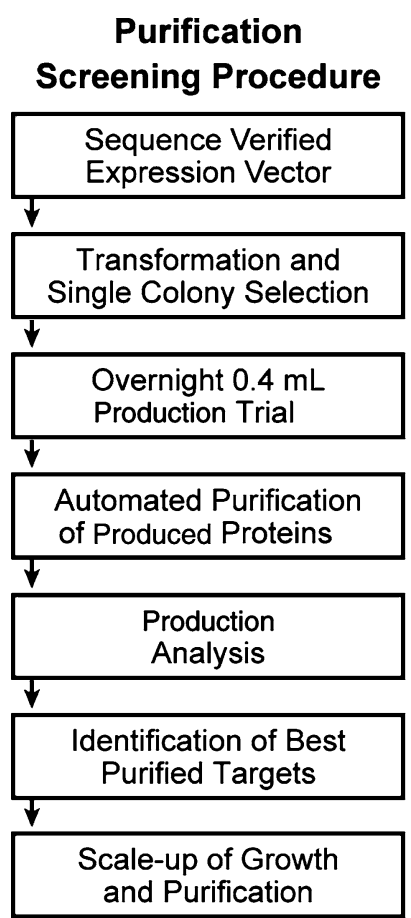

Fig. 8 Schematic of a purification screening protocol. Steps from obtaining a sequence-verified target in auto-cleavage vector pVP62K to identification of purified proteins. The transformed expression host is grown in auto-induction medium. Cells from production trials are loaded into the Maxwell 16 instrument for automated purification, and purified proteins are detected by Caliper LC90 capillary electrophoresis. Successful purification of a protein from auto-cleavage expression with yield exceeding $50 \mu \mathrm{g} / \mathrm{ml}$ of culture medium indicates feasibility of scale-up efforts effectively address either the variability in proteolysis of fusion proteins that are often used to express eukaryotic proteins in E. coli or the behavior of the liberated targets after proteolysis. By adopting this screening approach, the decision to scale-up protein production can be based on the ability to express, proteolyze, and purify the protein, and as indicated here, this decision can be extended to the ability to include other information such as acceptable ${ }^{1} \mathrm{H}-{ }^{15} \mathrm{~N}$ HSQC spectra or evidence of crystallization.

Table 2 contains information on another troublesome set of eukaryotic proteins, those with $\mathrm{pI} \sim 8$ or greater (A2, A3, A4, A10, B1, B2). Purification screening would provide important insight into the behavior of these proteins, which often perform well as fusion proteins in total production and solubility properties, but which often fail in proteolysis or stability after proteolysis $(\sim 70 \%$, unpublished results). Thus, although the original pipeline screening suggested A2, A6, A10, and B1 should have been advanced to purification, each of these targets failed to achieve the desired threshold from the Maxwell purification for purified fusion protein and thus deserved a work stopped assignment. In contrast, the high pI protein A3 was purified in high yield as a fusion protein from the Maxwell and subsequently was released by TEV protease treatment (as in the original pipeline scoring), supporting the decision that this protein should be continued along the scale-up process. Further consideration of the results of these targets will be included in a broader study of the effect of the $\mathrm{N}$-terminal AIA tag on protein purification and structure determination statistics, which will be reported elsewhere.

\section{Scalability}

Scalability requires similar protein production behavior in small-scale screening, large-scale protein production, and, ultimately, protein purification. For proteins A8 and A9, the original small-scale screening reported these proteins were unsuitable because of a failure in TEV proteolysis, and this result was also determined after Maxwell purification. Among the four human embryonic stem cell proteins investigated, Tcl-1 was highly expressed by autoinduction, underwent efficient in vivo proteolysis from MBP, and was successfully purified with an estimated volumetric productivity of $7.5 \mu \mathrm{g} / \mathrm{ml}$. Two other stem cell proteins (C10orf96 and NPM2), were also purified, but their yields were not sufficient to indicate feasibility of the scale-up as a structural target. Nevertheless, the method yielded enough purified protein that some functional studies or other analyses could be undertaken. By coupling in vivo cleavage with automated purification, failure to proteolyze the His8-target from the fusion protein and cryptic insolubility of the His8-target after proteolysis are 
signaled by failure in automated purification. Since both of these results are diagnostic of likely failures in large-scale purification, the purification screening approach gave valuable insight into the behavior of the human stem cell protein CCNF and the others before any significant scaleup efforts were undertaken.

We demonstrated how the amount of His8-target successfully purified from a single Maxwell 16 lane can be used to determine the scale-up factor required to prepare samples for screening either by ${ }^{1} \mathrm{H}_{-}{ }^{15} \mathrm{~N}$ NMR for folding status ( $\sim 700 \mu \mathrm{g}$ of a $25 \mathrm{kDa}$ or less protein set as the deliverable) or by microfluidic screening for crystallization $(\sim 10 \mu \mathrm{g}$ of protein set as the deliverable). This scaling approach was demonstrated for both Tcl-1 and AIA-GFP. Decreasing the amount of protein required for initial structural screening through the use of small NMR tubes, cryoprobes, and by $\mathrm{nL}$ liquid handling effectively complements the ability to produce moderate amounts of protein in the cost-effective manner described here. Automated methods for removal of the His8-tag during the Maxwell 16 run would also be desirable, and these investigations are in progress.

\section{Time}

CESG starts all expression work on eukaryotic proteins with sequence verified clones [32, 53]. Uncertainties in gene models and errors from primer synthesis are addressed by this effort, while immediate sequence verification of a cloned gene also supports reliable transfer into other expression vectors. Expression plasmids transformed into E. coli B834 can be available for purification screening studies after $24 \mathrm{~h}$, and growth from single colony transformants can be completed in $48 \mathrm{~h}$ using our autoinduction approach ( $24 \mathrm{~h}$ of growth in non-inducing medium followed by $24 \mathrm{~h}$ of growth in inducing medium). Auto-induced cultures can be immediately loaded onto the Maxwell 16 apparatus, with parallel processing of 16 samples in $45 \mathrm{~min}$. Thus a complete 96-well plate of different targets (or variants of the same target) could be purified and analyzed for protein expression by the automated capillary electrophoresis in less than $7 \mathrm{~h}$. In the work flow of Fig. 8, the best performing targets, provisionally defined as those obtained from in vivo cleavage and automated purification in yield of $50 \mu \mathrm{g} / \mathrm{ml}$ or greater, can be identified in about 4 days, with most of the elapsed time allotted to overnight culture growths or automated protein purification.

\section{Cost}

Auto-induction media are chemically defined and assembled from inexpensive components. Furthermore, the cost of labeled amino acids $\left({ }^{15} \mathrm{~N}\right.$ or Se-Met) is minimal for the initial screening due to the small cell culture volume required. For the example shown in Fig. 4, the cost for all reagents for the auto-induction and automated purification of the ${ }^{15} \mathrm{~N}$-labeled sample was less than $\$ 50$. The simple instrumentation required for the auto-induction and the Maxwell 16 purification may allow wide access to this approach, and the minimal hands-on effort required to complete the analysis through to purified protein is another considerable operational advantage.

Capillary electrophoresis has several advantages relative to slab gel electrophoresis. Although the instrument is more expensive than a standard power supply, electrophoresis equipment, and gel documentation system, the average price per sample analysis ( $\sim \$ 0.67$ per lane of analysis) using the LC90 chip is less than pre-cast polyacrylamide gels ( $\sim \$ 1.17$ per lane of analysis). Other advantages of capillary electrophoresis include automated operation, rapid processing time, digital information capture, and quantitative analysis of electropherograms. This work shows that the quantitative analysis of protein yield from a small-scale expression can be used as a predictive tool for scale-up feasibility.

\section{Other applications of this approach}

The automated protein purification process described here has other potential uses. This process can facilitate evaluation of different vector designs and arrays of different expression hosts. For functional studies, banks of sitedirected or randomly mutated proteins can be prepared and purified in amounts sufficient for catalytic screening. This may facilitate protein engineering for new traits that can be assayed such as changes in catalytic activity, thermal stability, or other desirable properties. In many cases, the amounts of protein recovered by the automated purification (Tables 2 and 3) should be adequate to initiate these functional studies. Surface entropy reduction analysis could also be facilitated through an effective sorting of protein variants that maintain sufficient stability to be purified. The delivery of small quantities of purified proteins for examination by micro-crystallization techniques or NMR analysis before significant effort is placed into purifying large quantities also has demonstrable advantages.

For eukaryotic proteins, domain engineering is an important experimental focus. It is clear that multiple changes at the $\mathrm{N}$ - and $\mathrm{C}$-terminus may be required to identify the best performing variant. Through the use of purification screening, it is efficient to express, purify, and examine engineered domains for improved solubility properties as part of the experimental process. 
Acknowledgements The authors thank other members of the University of Wisconsin-Madison, Center for Eukaryotic Structural Genomics for their assistance and support. Special thanks are offered to Michael A. Goren, Karl Nichols, Maggie Harteau, Steve Sarles and Stuart Ballard. The authors also thank Professor James Thomson (University of Wisconsin-Madison, Department of Anatomy and Genome Center) for identification of the human embryonic stem cell proteins used in this work. This work was supported by the National Institutes of Health, Protein Structure Initiative grant U54 GM074901 (J.L.M., PI; G.N.P., Co-Investigator; B.G.F.; Co-Investigator) and a sponsored research agreement from Promega Corporation to B.G.F. J.G.M. is supported by an NHGRI training grant to the Genomic Sciences Training Program (5T32HG002760). L.J.B. is supported by NIH grant GM50853 and National Science Foundation grant MCB0316232 to B.G.F.

Open Access This article is distributed under the terms of the Creative Commons Attribution Noncommercial License which permits any noncommercial use, distribution, and reproduction in any medium, provided the original author(s) and source are credited.

\section{References}

1. Knaust RK, Nordlund P (2001) Screening for soluble expression of recombinant proteins in a 96-well format. Anal Biochem 297:79-85

2. Stevens RC (2000) Design of high-throughput methods of protein production for structural biology. Structure 8:R177-185

3. Kawasaki M, Inagaki F (2001) Random PCR-based screening for soluble domains using green fluorescent protein. Biochem Biophys Res Commun 280:842-844

4. King DA, Hall BE, Iwamoto MA, Win KZ, Chang JF, Ellenberger $T$ (2006) Domain structure and protein interactions of the silent information regulator Sir3 revealed by screening a nested deletion library of protein fragments. J Biol Chem 281:2010720119

5. Reich S, Puckey LH, Cheetham CL, Harris R, Ali AA, Bhattacharyya U, Maclagan K, Powell KA, Prodromou C, Pearl LH, Driscoll PC, Savva R (2006) Combinatorial domain hunting: an effective approach for the identification of soluble protein domains adaptable to high-throughput applications. Protein Sci 15:2356-2365

6. Kato A, Maki K, Ebina T, Kuwajima K, Soda K, Kuroda Y (2007) Mutational analysis of protein solubility enhancement using short peptide tags. Biopolymers 85:12-18

7. Zhou P, Lugovskoy AA, Wagner G (2001) A solubilityenhancement tag (SET) for NMR studies of poorly behaving proteins. J Biomol NMR 20:11-14

8. Garrard SM, Longenecker KL, Lewis ME, Sheffield PJ, Derewenda ZS (2001) Expression, purification, and crystallization of the RGS-like domain from the Rho nucleotide exchange factor, PDZRhoGEF, using the surface entropy reduction approach. Protein Expr Purif 21:412-416

9. Derewenda ZS, Vekilov PG (2006) Entropy and surface engineering in protein crystallization. Acta Crystallogr D Biol Crystallogr 62:116-124

10. Rayment I (1997) Reductive alkylation of lysine residues to alter crystallization properties of proteins. Methods Enzymol 276:171179

11. Galvao-Botton LM, Katsuyama AM, Guzzo CR, Almeida FC, Farah CS, Valente AP (2003) High-throughput screening of structural proteomics targets using NMR. FEBS Lett 552:207213
12. Scheich C, Leitner D, Sievert V, Leidert M, Schlegel B, Simon B, Letunic I, Bussow K, Diehl A (2004) Fast identification of folded human protein domains expressed in $E$. coli suitable for structural analysis. BMC Struct Biol 4:4

13. Chayen NE, Saridakis E (2002) Protein crystallization for genomics: towards high-throughput optimization techniques. Acta Crystallogr D Biol Crystallogr 58:921-927

14. Kimber MS, Vallee F, Houston S, Necakov A, Skarina T, Evdokimova E, Beasley S, Christendat D, Savchenko A, Arrowsmith CH, Vedadi M, Gerstein M, Edwards AM (2003) Data mining crystallization databases: knowledge-based approaches to optimize protein crystal screens. Proteins 51:562-568

15. Yee AA, Savchenko A, Ignachenko A, Lukin J, Xu X, Skarina T, Evdokimova E, Liu CS, Semesi A, Guido V, Edwards AM, Arrowsmith $\mathrm{CH}$ (2005) NMR and X-ray crystallography, complementary tools in structural proteomics of small proteins. J Am Chem Soc 127:16512-16517

16. Brenner SE (2000) Target selection for structural genomics. Nat Struct Biol 7(Suppl):967-969

17. Smialowski P, Martin-Galiano AJ, Cox J, Frishman D (2007) Predicting experimental properties of proteins from sequence by machine learning techniques. Curr Protein Pept Sci 8:121-133

18. Goh CS, Lan N, Douglas SM, Wu B, Echols N, Smith A, Milburn D, Montelione GT, Zhao H, Gerstein M (2004) Mining the structural genomics pipeline: identification of protein properties that affect high-throughput experimental analysis. J Mol Biol 336:115-130

19. Watson JD, Todd AE, Bray J, Laskowski RA, Edwards A, Joachimiak A, Orengo CA, Thornton JM (2003) Target selection and determination of function in structural genomics. IUBMB Life 55:249-255

20. Brodsky O, Cronin CN (2006) Economical parallel protein expression screening and scale-up in Escherichia coli. J Struct Funct Genomics 7:101-108

21. Canaves JM, Page R, Wilson IA, Stevens RC (2004) Protein biophysical properties that correlate with crystallization success in Thermotoga maritima: maximum clustering strategy for structural genomics. J Mol Biol 344:977-991

22. Nguyen H, Martinez B, Oganesyan N, Kim R (2004) An automated small-scale protein expression and purification screening provides beneficial information for protein production. J Struct Funct Genomics 5:23-27

23. Page R, Moy K, Sims EC, Velasquez J, McManus B, Grittini C, Clayton TL, Stevens RC (2004) Scalable high-throughput microexpression device for recombinant proteins. Biotechniques 37:364, 366, 368 passim

24. Peti W, Page R, Moy K, O’Neil-Johnson M, Wilson IA, Stevens RC, Wuthrich K (2005) Towards miniaturization of a structural genomics pipeline using micro-expression and microcoil NMR. J Struct Funct Genomics 6:259-267

25. Smialowski P, Schmidt T, Cox J, Kirschner A, Frishman D (2006) Will my protein crystallize? A sequence-based predictor. Proteins 62:343-355

26. Sugar FJ, Jenney FE Jr, Poole FL 2nd, Brereton PS, Izumi M, Shah C, Adams MW (2005) Comparison of small- and large-scale expression of selected Pyrococcus furiosus genes as an aid to high-throughput protein production. J Struct Funct Genomics 6:149-158

27. Vincentelli R, Bignon C, Gruez A, Canaan S, Sulzenbacher G, Tegoni M, Campanacci V, Cambillau C (2003) Medium-scale structural genomics: strategies for protein expression and crystallization. Acc Chem Res 36:165-172

28. Tyler RC, Sreenath HK, Singh S, Aceti DJ, Bingman CA, Markley JL, Fox BG (2005) Auto-induction medium for the production of [U-15N]- and [U-13C, U-15N]-labeled proteins for 
NMR screening and structure determination. Protein Expr Purif 40:268-278

29. Sreenath HK, Bingman CA, Buchan BW, Seder KD, Burns BT, Geetha HV, Jeon WB, Vojtik FC, Aceti DJ, Frederick RO, Phillips GN Jr, Fox BG (2005) Protocols for production of selenomethionine-labeled proteins in 2-1 polyethylene terephthalate bottles using auto-induction medium. Protein Expr Purif 40:256-267

30. Jeon WB, Aceti DJ, Bingman CA, Vojtik FC, Olson AC, Ellefson JM, McCombs JE, Sreenath HK, Blommel PG, Seder KD, Burns BT, Geetha HV, Harms AC, Sabat G, Sussman MR, Fox BG, Phillips GN Jr (2005) High-throughput purification and quality assurance of Arabidopsis thaliana proteins for eukaryotic structural genomics. J Struct Funct Genomics 6:143-147

31. Tyler RC, Aceti DJ, Bingman CA, Cornilescu CC, Fox BG, Frederick RO, Jeon WB, Lee MS, Newman CS, Peterson FC, Phillips GN Jr, Shahan MN, Singh S, Song J, Sreenath HK, Tyler EM, Ulrich EL, Vinarov DA, Vojtik FC, Volkman BF, Wrobel RL, Zhao Q, Markley JL (2005) Comparison of cell-based and cell-free protocols for producing target proteins from the Arabidopsis thaliana genome for structural studies. Proteins 59:633-643

32. Blommel PG, Martin PA, Wrobel RL, Steffen E, Fox BG (2006) High efficiency single step production of expression plasmids from cDNA clones using the flexi vector cloning system. Protein Expr Purif 47:562-570

33. Blommel PG, Becker KJ, Duvnjak P, Fox BG (2007) Enhanced bacterial protein expression during auto-induction obtained by alteration of lac repressor dosage and medium composition. Biotechnol Prog 23:585-598

34. Sambrook J, Russell DW (2001) Molecular cloning: a laboratory manual. Cold Spring Harbor Laboratory Press, Cold Spring Harbor, New York, pp 15.44-15.48

35. Klein RD, Wells RD (1982) Effects of neighboring DNA homopolymers on the biochemical and physical properties of the Escherichia coli lactose promoter. I. Cloning and characterization studies. J Biol Chem 257:12954-12961

36. Patterson GH, Knobel SM, Sharif WD, Kain SR, Piston DW (1997) Use of the green fluorescent protein and its mutants in quantitative fluorescence microscopy. Biophys J 73:2782-2790

37. Yang TT, Cheng L, Kain SR (1996) Optimized codon usage and chromophore mutations provide enhanced sensitivity with the green fluorescent protein. Nucleic Acids Res 24:4592-4593

38. Crameri A, Whitehorn EA, Tate E, Stemmer WP (1996) Improved green fluorescent protein by molecular evolution using DNA shuffling. Nat Biotechnol 14:315-319

39. Prodromou C, Pearl LH (1992) Recursive PCR: a novel technique for total gene synthesis. Protein Eng 5:827-829

40. Casimiro DR, Toy-Palmer A, Blake RC 2nd, Dyson HJ (1995) Gene synthesis, high-level expression, and mutagenesis of
Thiobacillus ferrooxidans rusticyanin: his 85 is a ligand to the blue copper center. Biochemistry 34:6640-6648

41. Casimiro DR, Wright PE, Dyson HJ (1997) PCR-based gene synthesis and protein NMR spectroscopy. Structure 5:1407-1412

42. Sambrook J, Fritsch EF, Maniatis T (2001) Molecular cloning, a laboratory manual. Cold Spring Harbor, Cold Spring Harbor Laboratory Press, New York

43. Wood WB (1966) Host specificity of DNA produced by Escherichia coli: bacterial mutations affecting the restriction and modification of DNA. J Mol Biol 16:118-133

44. Arber W (1964) Host specificity of DNA produced by Escherichia coli. 3 . Effects on transduction mediated by lambda Dg. Virology 23:173-182

45. Studier FW (2005) Protein production by auto-induction in high density shaking cultures. Protein Expr Purif 41:207-234

46. Blommel PG, Fox BG (2007) A combined approach to improving large-scale production of tobacco etch virus protease. Protein Expr Purif 55(1):53-68

47. The CCP4 suite: programs for protein crystallography (1994) Acta Crystallogr D Biol Crystallogr 50:760-763

48. Emsley P, Cowtan K (2004) Coot: model-building tools for molecular graphics. Acta Crystallogr D Biol Crystallogr 60:2126-2132

49. Murshudov GN, Vagin AA, Dodson EJ (1997) Refinement of macromolecular structures by the maximum-likelihood method. Acta Crystallogr D Biol Crystallogr 53:240-255

50. Leahy DJ, Hendrickson WA, Aukhil I, Erickson HP (1992) Structure of a fibronectin type III domain from tenascin phased by MAD analysis of the selenomethionyl protein. Science 258:987-991

51. Blattner FR, Plunkett G 3rd, Bloch CA, Perna NT, Burland V, Riley M, J. Collado-Vides, Glasner JD, Rode CK, Mayhew GF, Gregor J, Davis NW, Kirkpatrick HA, Goeden MA, Rose DJ, Mau B, Shao Y (1997) The complete genome sequence of Escherichia coli K-12. Science 277:1453-1474

52. Welch RA, Burland V, Plunkett G 3rd, Redford P, Roesch P, Rasko D, Buckles EL, Liou SR, Boutin A, Hackett J, Stroud D, Mayhew GF, Rose DJ, Zhou S, Schwartz DC, Perna NT, Mobley HL, Donnenberg MS, Blattner FR (2002) Extensive mosaic structure revealed by the complete genome sequence of uropathogenic Escherichia coli. Proc Natl Acad Sci USA 99:1702017024

53. Thao S, Zhao Q, Kimball T, Steffen E, Blommel PG, Riters M, Newman CS, Fox BG, Wrobel RL (2004) Results from highthroughput DNA cloning of Arabidopsis thaliana target genes using site-specific recombination. J Struct Funct Genomics 5:267-276 